\title{
BIOCHEMICAL MUTANT IN BARLEY RENDERS CHEMICAL STABILIZATION OF BEER SUPERFLUOUS
}

\author{
by \\ D. von WETTSTEIN \\ and \\ BARBRO JENDE-STRID \\ Department of Physiology, Carlsberg Laboratory \\ Gamle Carlsberg Vej 10 - DK-2500 Copenhagen, Valby \\ and \\ B. AHRENST-LARSEN \\ and \\ J. A. SøRENSEN \\ Department of Brewing Chemistry, Carlsberg Research Laboratory, \\ Gamle Carlsberg Vej 10, DK-2500 Copenhagen, Valby
}

\begin{abstract}
Key words: proanthocyanidins, anthocyanogens, polyphenols, catechins, flavonoids, haze stability, shelf life of beer
\end{abstract}

The recessive mutant ant-13 isolated from Foma barley after a mutagen treatment with ethyl methanesulfonate is shown to be blocked in the formation of anthocyanins, catechins and proanthocyanidins (= anthocyanogens). The mutant has been propagated, malted on a pilot scale and the malt used for pilot brews of beer. Foma barley has been malted and brewed for comparison. Malt, wort and beer made from the mutant was free of the polyphenols that are found, when Foma is used as raw material. The beer brewed from the proanthocyanidinand catechin-free mutant had satisfactory haze stability. In colour and flavour ant-13 beer was indistinguishable from Foma beer, but in haze stability the former was drastically superior to the latter.

\section{INTRODUCTION}

Permanent haze and chill haze in beer are caused by precipitation of proteins with polyphenols which derive from barley and hops (17). The polyphenols most prominent in this respect are the proanthocyanidins - frequently called anthocyanogens - and the catechins which tend to form polymers. The simple phenols present in the barley grain such as the phenolic and hydroxycinnamic acids as well as 
their esters and glycosides, and the coumarines contribute apparently little to haze formation (9). The proanthocyanidins, the anthocyanins and the catechins from the barley grain precipitate some proteins during the boiling of the wort and thereby participate in the formation of the break. The polyphenols remaining after removal of the break are primary sources for chill haze and permanent haze formation in beer.

In order to retard haze formation polyphenols can be removed in part with e.g. polyvinylpyrrolidone (PVP), its insoluble polymer Polyclar AT or nylon 66. The use of barley grains lacking proanthocyanidins and catechins is expected to yield beer with improved haze stability. Trolle (26) has suggested to look for barley varieties with a low content of proanthocyanidins, but surveys for the content of proanthocyanidins and catechins in different barley cultivars including anthocyanin-free varieties have revealed little quantitative variations of these compounds $(20,22)$. We have therefore studied the flavonoid contents of a series of induced mutants affecting anthocyanin pigmentation in various plant parts (12). One mutant, named ant-13, in the variety Foma turned out to be practically free of proanthocyanidins and catechins in the grains. The mutant has been propagated, malted and used for brewing beer. The beer made from this anthocyanin-, proanthocyanidin- and catechinfree mutant revealed good haze stability.

\section{MATERIALS}

The flavonoid content was analysed in 53 recessive gene mutants affecting anthocyanin pigmentation contained in the collection of artificially induced mutants kept at the Swedish Seed Association, Svalöv. The mutants in this collection have been induced and isolated over the past 45 years by $\dot{A}$. GustafsSon, N. NyboM, L. EhrenberG, U. LuNDQViST and D. VON WETTSTEIN (cf. 12). For genes controlling anthocyanin pigmentation the designation rubrum and the symbol rub were proposed by
GuSTAFSSON, HAGBERG, LUNDQVIST and PERSSON in 1969 (12). Subsequently the International Committee for assigning barley gene symbols has agreed that gene symbols starting with the letter $r$ should be used only for genes controlling resistance towards diseases. It is therefore proposed that the gene symbol ant be reserved for genes affecting the anthocyanin, anthocyanidin, and proanthocyanidin content in barley.

For the original screening, grains of the 53 mutants and their mother varieties were kindly supplied by Professor ÁKE Gustafsson and Mrs. UDDA LUNDQVIST and grown in observation plots at the experimental farm at Allindemagle. Of the mutants, 42 have originated in the variety Foma, 10 in the variety Bonus and 1 in the variety Kristina after mutagen treatments with $\gamma$-rays, neutrons, different sulfonates, ethyleneimine or $\mathrm{N}$-methyl-N-nitrosourethane. As to anthocyanin pigmentation the mutants comprise 42 classified visually as anthocyanin-free or anthocyanin-poor, 4 as anthocyanin-rich, 6 as red awns, and 1 as red stem. A detailed genetic and chemical analysis of the 53 mutants will be presented by B. JENDE-STRID in a subsequent paper. Mutant ant-13 is not allelic to any of the other mutants and has been isolated in 1960 after a mutagen treatment of resting grains of Forma with a solution of $0.25 \% \mathrm{v} / \mathrm{v}$ ethyl methanesulfonate.

\section{METHODS}

\subsection{Determination of anthocyanidins and proanthocyanidins}

The analysis has been modified from that described by HARRIS and RICKETTS (14). After determination of the grains dry weight, $5.0 \mathrm{~g}$ freshly prepared barley flour (Prometer mill) was extracted while rotating with $50 \mathrm{ml}$ of $60 \%$ $\mathrm{v} / \mathrm{v}$ ethanol containing $1 \% \mathrm{w} / \mathrm{v}$ ascorbic acid for one hour. After centrifugation for $10 \mathrm{~min}$ at $4100 \mathrm{x} g$ in a Sorvall refrigerated centrifuge, the sediment was re-extracted in the same way. A total of four successive extractions yielded 97 $99 \%$ of the proanthocyanidins and anthocyani- 
dins present in the grain. The volume of the combined extracts was adjusted to $250 \mathrm{ml}$ with the extraction medium.

An aliquot of $10 \mathrm{ml}$ of extract, wort or beer was pipetted into a $25 \mathrm{ml}$ graduated centrifuge tube, $0.5 \mathrm{~g}$ of polyamide powder (Divergan) and the sample shaken for $40 \mathrm{~min}$. After centrifugation for $5 \mathrm{~min}$ at $3000 \mathrm{x}$ g the pellet consisting of polyamide powder (Divergan) with the absorbed proanthocyanidins and anthocyanidins was washed with distilled water and recentrifuged. For cleavage of proanthocyanidins into their anthocyanidin and catechin moieties, $20 \mathrm{ml}$ of butanol and conc. $\mathrm{HCl}(5: 1, v / v)$ were added and the sample was placed in a boiling water bath for $30 \mathrm{~min}$. After cooling to room temperature, the volume was adjusted to $25 \mathrm{ml}$ and the anthocyanidin concentration determined by measuring the extinction of the solution at $550 \mathrm{~nm}$, which is close to the absorption maximum for cyanidin in butanol-HCl. The extinction was measured in a Zeiss PMQ III spectrophotometer against a blank of distilled water treated in the same way as the barley flour extract. Proanthocyanidin content of the solution was calculated using a calibration curve obtained with known amounts of leucocyanidin hydrate (Fluka) dissolved in butanol-HCl. Usually two samples were analysed in parallel. If the difference in extinction was greater than 0.010 a third analysis was made. The mean of the two closest values of the extinction was used for calculation of the proanthocyanidin content.

\subsection{Simultaneous determination of proanthocyanidins and catechins in barley grains, malt, wort and beer}

The analysis has been worked out by DADIC (7) and DADIC and MORRISON (8). $5.0 \mathrm{~g}$ freshly ground barley or malt (Prometer mill) was extracted by shaking with $100 \mathrm{ml}$ of $50 \% \mathrm{v} / \mathrm{v}$ ethanol and $50 \mu \mathrm{l}$ saturated vitamin $\mathrm{E}$ (D. tocopherolsuccinate, Valby Pharmacy) solution for one hour. After centrifugation for $10 \mathrm{~min}$ at $4100 \mathrm{x} \mathrm{g}$ in a Sorvall refrigerated centrifuge, the supernatant liquor was filtered on a Büchner funnel. The filtrate was adjusted to $100 \mathrm{ml}$ with
$50 \%$ ethanol and used immediately. $6.0 \mathrm{~g}$ of Nylon 66 powder was added to $100 \mathrm{ml}$ of prepared extract. If wort or beer was analysed, $6.0 \mathrm{~g}$ of Nylon 66 was added to $60 \mathrm{ml}$ of degassed beer or wort and $60 \mathrm{ml}$ of distilled water. The suspension was stirred magnetically for $30 \mathrm{~min}$ and then filtered through a membrane filter (Millipore 1.2 microns). The filtrate was set aside for preparation of the blank. Transfer of Nylon 66 with the adsorbed proanthocyanidins and catechins from the adsorption vessel to the filter and subsequent washing was accomplished with $200 \mathrm{ml}$ of distilled water. The washed Nylon 66 powder was air-dried for $15 \mathrm{~min}$ and then $90 \mathrm{ml}$ of propanol and conc. $\mathrm{HCl}(5: 1 \mathrm{v} / \mathrm{v})$ or $90 \mathrm{ml}$ of butanol and conc. $\mathrm{HCl}(5: 1 \mathrm{v} / \mathrm{v})$ was added. The mixture was refluxed for $30 \mathrm{~min}$ in a boiling water bath with magnetic stirring. After cooling to room temperature, the extinction of the solution was measured at 455 and $545 \mathrm{~nm}$ which is close to the absorption maxima for catechin and cyanidin on a Zeiss PMQ III spectrophotometer using a blank prepared of the filtrate from the membrane filtration. The blank was treated in the same way as the barley flour extract. Estimation of the proanthocyanidin and catechin content was made using calibration curves obtained with known amounts of cyanidin chloride and $\mathrm{D}-(+)$-catechin dissolved in propanol- $\mathrm{HCl}$ or butanol- $\mathrm{HCl}$. Binary analysis was applied to calculate the concentrations of proanthocyanidin and catechin.

\subsection{Determination of polyphenols in wort and beer}

The method of determination of total polyphenols in wort and beer has been developed by JeRuMANIS (18). The beer was degassed by shaking. Hazy wort and beer was clarified by centrifugation.

Reagents: CM/EDTA reagent: $1 \% \mathrm{w} / \mathrm{v}$ solution of low viscosity carboxymethylcellulose (British Drug House) containing $0.2 \% \mathrm{w} / \mathrm{v}$ disodiumethylene-diamine tetraacetate. Ferric reagent: $3.5 \% \mathrm{w} / \mathrm{v}$ green ammonium ferric citrate. Ammonia reagent: Conc. ammonia diluted with 2 volumes of distilled water.

Ten $\mathrm{ml}$ of sample and $8 \mathrm{ml}$ of CM/EDTA rea- 
gent were mixed and $0.5 \mathrm{ml}$ of ferric reagent added and mixed. Then $0.5 \mathrm{ml}$ of ammonia reagent was added and the solution thoroughly mixed. The volume was adjusted to $25 \mathrm{ml}$ with distilled water and the solution well mixed again and left to stand for $10 \mathrm{~min}$. The polyphenols of the sample reacted with the ferric iron in the alkaline solution and a red or red-brown colour was produced. The extinction was measured on a Zeiss PMQ II spectrophotometer at $525 \mathrm{~nm}$ against a blank prepared from the same solution as the test sample. The polyphenols had been removed from the blank by treatment with washed Polyclar AT (General Aniline and Film $\mathrm{Co}$.). Otherwise the blank was treated in the same way as the test sample.

Concentration of polyphenols in ppm is given by: $\mathrm{E}_{525} \times 630$.

\subsection{Pilot malting}

Portions of $14 \mathrm{~kg}$ of barley were steeped and germinated in a rotating drum made of stainless steel net and surrounded by a plastic housing. Steeping was carried out over 2 days with alternating periods of several hours in water and in air at $14-15^{\circ} \mathrm{C}$ until a moisture content of $41-43 \%$ was reached. During germination for 5-6 days at $12^{\circ} \mathrm{C}$, the moisture content was maintained by adding water dropwise. Air with the desired temperature was supplied through the upper part of the housing. The kilning was carried out by placing the green malt in a heating cabinet. Over the first few hours the temperature of the malt increased to $50^{\circ} \mathrm{C}$ and was kept at this temperature up to 10 hours, whereafter the temperature was raised over 3 hours to reach $78^{\circ} \mathrm{C}$. Curing was done at this temperature for additional 3 hours. The cured malt was re-placed in the drum and the rootlets were removed by fast rotation.

\subsection{Pilot brewing}

$10 \mathrm{~kg}$ of ground malt was mashed in the pilot brewery (1) with 421 of deionized water by infusion mashing without adjuncts. The fol- lowing standard mashing procedure was employed:

$30 \mathrm{~min}$ at $52^{\circ} \mathrm{C}$, heating from $52^{\circ} \mathrm{C}$ to $63^{\circ} \mathrm{C}$ in $20 \mathrm{~min}, 60 \mathrm{~min}$ at $63^{\circ} \mathrm{C}$, heating from $63^{\circ} \mathrm{C}$ to $78^{\circ} \mathrm{C}$ in $40 \mathrm{~min}, 10 \mathrm{~min}$ at $78^{\circ} \mathrm{C}$. A lauter tub was used for the wort filtration at $73^{\circ} \mathrm{C}$, and four spargings with $6+6+10+151$ of deionized water were performed. Total filtration time for 61-62 1 of wort amounted to about $160 \mathrm{~min}$. After addition of $8.7 \mathrm{~g}$ tannin-free hop extract from Horst Company, the wort was boiled for $90 \mathrm{~min}$ and cooled to $5^{\circ} \mathrm{C}$ by standing overnight in a wort holding vessel cooled with ice water. On the following day the cold wort was separated from the hot and cold break, transferred to two 301 fermentation vessels and pitched with yeast, Saccharomyces carlsbergensis strain $U$, from which possibly adhering polyphenols had been removed by washing the cells six times with water. The amount of pitching yeast was $90 \mathrm{~g}$ per $28 \mathrm{~kg}$ of wort. The fermentation vessels were placed in a water thermostat at $10^{\circ} \mathrm{C}$. After fermentation for one week, the beer was racked into two 251 storage tanks with $\mathrm{CO}_{2}$-pressure and placed in a refrigerated cabinet. During 6 weeks of storage, the beer temperature was decreased gradually from $5^{\circ} \mathrm{C}$ to $-1^{\circ} \mathrm{C}$. The beer was filtered through $20 \times 20 \mathrm{~cm}$ Seitz K-7 sheets and the $\mathrm{CO}_{2}$ content adjusted to $0.5 \%$. Bottling and crowning were carried out manually, the bottles being knocked to reduce the air content in the headspace. The bottled beer was pasteurized at $62^{\circ} \mathrm{C}$ for $20 \mathrm{~min}$.

\subsection{Analyses of barley, malt, wort and beer}

Determination of moisture content and sieving tests of the barley used for pilot malting was carried out according to the procedures recommended by the Analysis Committee of the European Brewery Convention (2). Germination of the barley was tested by placing 100 grains on moistened sand in a covered petri dish at $16-18^{\circ} \mathrm{C}$ and counting the number of germinated grains after three days.

Total nitrogen and protein in barley, malt, wort and beer was determined by Kjeldahl analysis in a Kjel-Foss Automatic 16.210 (A/S 


\section{2 malonyl Co $-A$ acetyl Co-A}

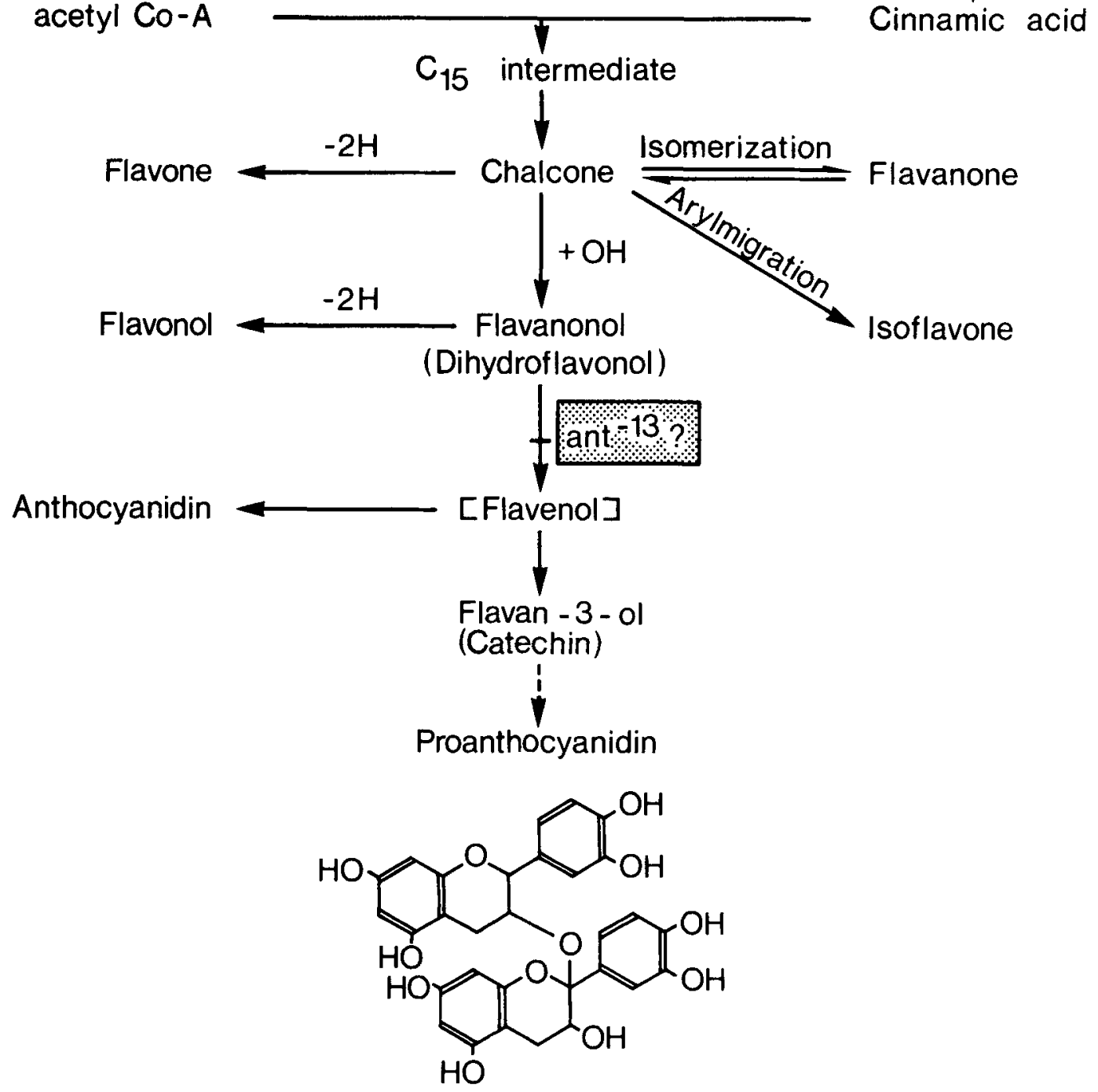

Shikimic acid<smiles>CCC(C)C</smiles>

Phenylalanine

Figure 1: Scheme for flavonoid biosynthesis according to HARBORNE (13), GRISEBaCH (11) and WeingeS et al. (27).

N. Foss Electric, Hillerød). $1.000 \mathrm{~g}$ of barley or malt, or alternatively $5.0 \mathrm{ml}$ of wort or beer were digested with $40 \mathrm{ml}$ conc. $\mathrm{H}_{2} \mathrm{SO}_{4}, 10 \mathrm{ml}$ $35 \% \mathrm{H}_{2} \mathrm{O}_{2}, 0.75 \mathrm{~g} \mathrm{HgO}$ and $15 \mathrm{~g} \mathrm{~K}_{2} \mathrm{SO}_{4}$ for 35 min. Destillation was carried out with a solution containing $400 \mathrm{~g} \mathrm{NaOH}$ and $80 \mathrm{~g} \mathrm{Na}_{2} \mathrm{~S}_{2} \mathrm{O}_{3}$ per 1 . The distillate was collected in $2 \%$ boric acid and titrated with standard acid. Protein is given as total nitrogen $\times 6.25$.

Analysis of malt for moisture content, extract 
Table I

Content of proanthocyanidins and catechins in grains of Foma barley and its mutant ant-13 in $\mathrm{mg} / 100 \mathrm{~g} \mathrm{dry}$ weight

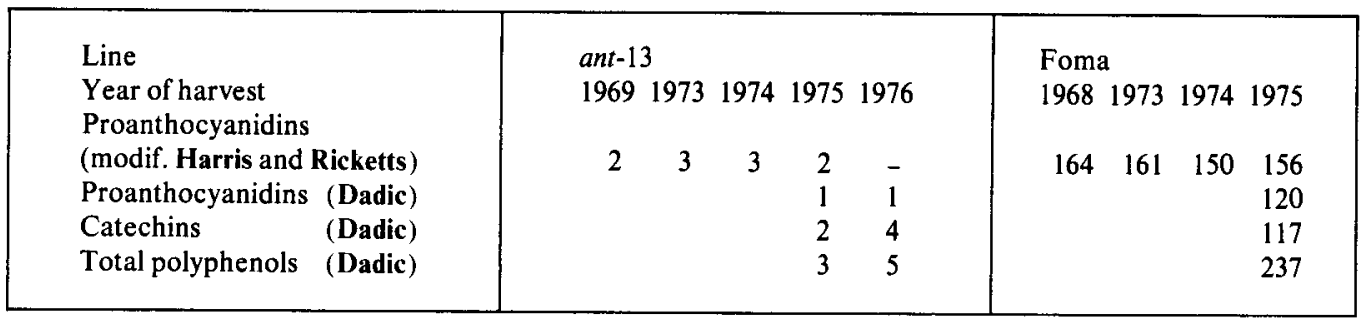

content, extract difference, diastatic power, Kolbach index and colour was done with the procedures recommended by the Analysis Committee of the European Brewery Convention (2). Alpha amylase was determined according to BLOM and BAK (3).

Wort was analysed for extract content, attenuation limit, bitterness and colour according to Analytica-EBC (2). Free Alpha amino nitrogen was estimated spectrophotometrically with 2,4,6-trinitrobenzene-1-sulfonic acid according to SATAKE et al. (23). Viscosity was determined with a Haake Kugelfall Viskosimeter (Haake, K. G., Berlin-Steglitz). Beer analyses were done according to Analytica-EBC specifications (2) except for $\mathrm{CO}_{2}$, which was measured after BLOM (4), head retention which was determined after BLOM (5), air in headspace, which was done according to SøRENSEN (25) and haze stability, which was also analysed according to CHAPON (6).

\section{RESULTS}

Proanthocyanidins are dimers of two catechin molecules, which upon hydrolysis give rise to one molecule of catechin and one molecule of anthocyanidin (27). The proanthocyanidin of barley has been assigned by Silbereisen and KrafFCZYK (24), the structure depicted in Figure 1. The biosynthetic pathway of flavonoids is well established up to dihydroflavonol as outlined in Figure $1(11,13)$, whereas the subsequent steps to anthocyani-
Table II

Analyses of the barley used for pilot malting

\begin{tabular}{|l|c|c|}
\hline & ant-13 & Foma \\
Moisture content, \% & 12.0 & 12.1 \\
Protein content, \% of dry weight & 17.2 & 16.2 \\
Germination after 3 days, \% & 100 & 100 \\
Sieving test: & & \\
above 2.8 mm, \% & 19 & 46 \\
" $2.5 \mathrm{~mm}, \%$ & 60 & 44 \\
$2.2 \mathrm{~mm}, \%$ & 19 & 9 \\
below $2.2 \mathrm{~mm}, \%$ & 2 & 1 \\
\hline
\end{tabular}

dins, catechins and proanthocyanidins are less well understood. A branch point is envisioned at the hypothetical flavenol intermediate and its existence is well supported by the analysis of the 42 anthocyanin-free or -poor mutants in barley. In 41 of them, the content of proanthocyanidins was the same as in their respective wild type in spite of the reduction or absence of the anthocyanidins. Consistently mutant ant-13 was deficient in proanthocyanidins, catechins and anthocyanidins in the grain (Table I), as well as in leaves, roots and stems. This mutation thus appears to block the conversion of dihydroflavonol to a common intermediate for anthocyanidins and catechins.

In 1974 the mutant was propagated and $26 \mathrm{~kg}$ of it used for the first pilot malting and brewing. The malt, wort and beer produced in this first experiment lacked measurable amounts of proanthocyanidins and the beer had drastically improved haze stability. A new series of 4 pilot maltings and brewings were therefore performed from the harvest of 1975 and 
Table III

Analyses of the four malt portions from ant-13 and Foma

\begin{tabular}{|c|c|c|c|c|}
\hline \multirow[b]{3}{*}{ Moisture content, \% } & \multicolumn{2}{|c|}{ ant -13} & \multicolumn{2}{|c|}{ Foma } \\
\hline & $\mathbf{a}$ & b & c & d \\
\hline & 4.5 & 4.5 & 4.6 & 4.8 \\
\hline Extract content, fine grind, $\%$ Plato & 78.1 & 78.0 & 78.8 & 78.9 \\
\hline Extract difference, $\%$ Plato & 5.1 & 5.0 & 4.3 & 4.6 \\
\hline Protein content, $\%$ of $d r y$ weight & 15.3 & 14.9 & 14.1 & 13.6 \\
\hline Alpha amylase, arbitrary units & 149 & 158 & 177 & 191 \\
\hline Diastatic power, Windisch-Kolbach units & 400 & 415 & 469 & 440 \\
\hline Kolbach index, \% & & 39 & 39 & 38 \\
\hline Wort colour, EBC units & 5.0 & 5.0 & 4.5 & 4.0 \\
\hline
\end{tabular}

Table IV

Analyses of the four portions of wort produced by pilot brewing from ant-13 and Forma malt

\begin{tabular}{|l|cc|cc|}
\hline & \multicolumn{2}{|c|}{ ant-13 } & \multicolumn{2}{c|}{ Foma } \\
& \multicolumn{2}{|c|}{$\mathrm{a}$} & $\mathrm{b}$ & \multicolumn{2}{c|}{$\mathrm{c}$} & $\mathrm{d}$ \\
Extract content, \% Plato & 9.72 & 10.87 & 10.22 & 10.00 \\
Attenuation limit, real, \% & 59 & 59 & 62 & 61 \\
Bitterness units & 30 & 28 & 31 & 33 \\
Total-N content, mg/l & - & 1398 & - & 1258 \\
Free alpha amino-N content, mg/l & 333 & 380 & 333 & 349 \\
pH & 5.6 & 5.8 & 5.7 & 5.7 \\
Colour, EBC units & 11 & 10 & 10 & 10 \\
Viscosity, mPa-s & 1.86 & 1.87 & 1.92 & 2.02 \\
\hline
\end{tabular}

\section{Table V}

Analyses of the beers produced by pilot brewing from ant-13 and Foma malt

\begin{tabular}{|c|c|c|c|c|}
\hline \multirow{12}{*}{$\begin{array}{l}\text { Original extract, \% Plato } \\
\text { Attenuation, real, \% } \\
\text { Bitterness units } \\
\text { Total-N content, } \mathrm{mg} / \mathrm{l} \\
\text { Free alpha amino-N content, } \mathrm{mg} / \mathrm{l} \\
\mathrm{pH} \\
\mathrm{CO}_{2} \text { content, \% } \\
\mathrm{Colour} \mathrm{EBC} \text { units } \\
\text { Head retention, seconds } \\
\text { Air in headspace, ml/bottle }\end{array}$} & \multicolumn{2}{|c|}{ ant -13} & \multicolumn{2}{|c|}{ Foma } \\
\hline & $a$ & $\mathrm{~b}$ & $\mathrm{c}$ & $\mathrm{d}$ \\
\hline & 9.7 & 9.7 & 10.3 & 10.1 \\
\hline & 59 & 58 & 61 & 61 \\
\hline & 21 & 20 & 19 & 20 \\
\hline & 1172 & 1153 & 1070 & 1050 \\
\hline & 203 & 239 & 239 & 222 \\
\hline & 4.7 & 4.6 & 4.7 & 4.7 \\
\hline & 0.46 & 0.51 & 0.49 & 0.51 \\
\hline & 8.5 & 7.5 & 7.5 & 7.5 \\
\hline & 109 & 114 & 111 & 108 \\
\hline & 1.7 & 1.6 & 1.3 & 1.3 \\
\hline $\begin{array}{c}\text { Flavour profile: United Breweries' } \\
\text { taste panel }\end{array}$ & \multicolumn{2}{|c|}{$\begin{array}{l}\text { Within acceptable } \\
\text { range for pilot } \\
\text { brews }\end{array}$} & \multicolumn{2}{|c|}{$\begin{array}{l}\text { Within acceptable } \\
\text { range for pilot } \\
\text { brews }\end{array}$} \\
\hline
\end{tabular}


Table VI

Polyphenols in barley, wort and beer

BARLEY:

Proanthocyanidin content, $\mathrm{mg} / 100 \mathrm{~g}$ dry weight (modif. Harris and Ricketts)

Catechin content, $\mathrm{mg} / 100 \mathrm{~g}$ dry weight (Dadic)

\section{WORT:}

Proanthocyanidin content, $\mathrm{mg} / \mathrm{l}$

(modif. Harris and Ricketts)

Catechin content, $\mathrm{mg} /$ (Dadic)

Total polyphenol content, $\mathrm{mg} /$ (Jerumanis)

BEER:

Proanthocyanidin content, $\mathrm{mg} / \mathrm{l}$

(modif. Harris and Ricketts)

Catechin content, $\mathrm{mg} /$ (Dadic)

Total polyphenol content, $\mathrm{mg} /$ (Jerumanis)

\begin{tabular}{|rr|rr|}
\hline \multicolumn{2}{|c|}{ ant-13 } & \multicolumn{2}{|c|}{ Foma } \\
& & \multicolumn{2}{|c|}{} \\
\multicolumn{2}{|c|}{0} & \multicolumn{2}{|c|}{115} \\
0 & $\mathrm{c}$ & $\mathrm{d}$ \\
\hline $\mathrm{a}$ & $\mathrm{b}$ & & \\
& & & \\
& & 38 & 43 \\
0 & 0 & 97 & 69 \\
38 & 31 & 105 & 102 \\
18 & 16 & & \\
& & & \\
& & 31 & 29 \\
0 & 0 & 61 & 61 \\
37 & 40 & 83 & 86 \\
7 & 7 & & \\
\hline
\end{tabular}

\section{Table VII}

Haze stability of the beers produced by the four pilot brewings

\begin{tabular}{|l|cc|cc|} 
& \multicolumn{2}{|c|}{ ant-13 } & \multicolumn{2}{|c|}{ Foma } \\
& $\mathrm{a}$ & $\mathrm{b}$ & $\mathrm{c}$ & $\mathrm{d}$ \\
Haze after bottling, EBC units & 0.9 & 0.8 & 0.9 & 0.9 \\
Chill haze after 5 days at $60^{\circ} \mathrm{C}$ and & 1.6 & 1.9 & 7.2 & 12.0 \\
1 day at $0^{\circ} \mathrm{C}, \mathrm{EBC}$ units & 3.3 & 3.5 & $9.8>12.5$ \\
Haze after $40 \mathrm{~min}$. at $-8^{\circ} \mathrm{C}, \mathrm{EBC}$ units (Chapon) & 1.7 & 1.6 & 1.3 & 1.3 \\
\hline Air in headspace, ml/bottle & & 1.6 \\
\hline
\end{tabular}

analyses of these are presented in Tables II to VII.

With the exception of a decrease in $\alpha$ amylase activity, the two malt portions of ant-13 are very similar to the two portions made from the feed and malting barley Foma (Table III). The malt analyses are within the normal specifications of the products from the pilot malting plant.

Likewise, the comparison of the wort analyses from the two portions of ant-13 with the two portions from Foma did not reveal significant differences (Table IV). Possibly the total N-content is slightly higher in the wort produced from ant-13 malt. This might be due to the absence of proanthocyanidins, which are believed to precipitate major amounts of proteins in the form of the break. It is surprising that the absence of proanthocyanidins did not increase the nitrogen content more.

Very close analytical results are also found for the two lots of beers made from ant-13 barley and Foma (Table V). The absence of proanthocyanidins in the beer (Table VI) did not affect the taste, as both beers were classified as within acceptable range for pilot brews by the United Breweries taste panel. With regard to Table VI it should be pointed out that the total polyphenol content is determined according to the JERUMANIS 
procedure, which clearly is not commensurable with the DADIC procedure. The catechin values observable in the wort and beer of ant-13 cannot be due to catechins from barley or malt as these lacked catechins according to the DADIC analysis. Experiments have shown that the tannin-free hope extract used in the brewings can contribute with no more than 3 $\mathrm{mg}$ catechin/l. It is possible that melanoidins formed during wort boiling interfere with catechin determinations and simulate the presence of catechins.

Comparison of haze stability between the beer produced from ant-13 and Foma is presented in Table VII. No difference is observed for the amount of haze present immediately after bottling. The chill haze developed after 5 days at $60^{\circ} \mathrm{C}$ and 1 day at $0^{\circ} \mathrm{C}$ is very satisfactorily reduced in the beer of ant13 when compared to that of Foma. Likewise, the CHAPON-test gave a highly significant reduction of chill haze developed in the beer from ant-13 barley as compared to beer from Foma barley. The use of ant-13 barley resulted in a beer with a haze stability that can be obtained with Foma barley only after treatment with chemical stabilizers. The selective elimination of proanthocyanidins from malt, wort and beer to the extent possible by malting mutant ant-13 and brewing beer from it cannot be achieved even by the use of very large quantities of Polyclar AT, as such treatments also remove most of the colour and flavour components from the beer. It can therefore be concluded that the selective removal of proanthocyanidins and catechins through biochemical mutations in barley can provide satisfactory haze stability and shelf life of beer without infringing on the possibilities to retain the desired colour and flavour components of the beer (28).

\section{DISCUSSION}

We have chosen in Figure 1 to reproduce the formula proposed by SILbEREISEN and KRAFFCZYK (24) for the proanthocyanidin of barley, as these authors have investigated this structure of proanthocyanidins of barley grains in detail. With regard to the interflavan linkage this formula is at variance with the formulas now accepted for the A-2 type and B type proanthocyanidins. The latter formulas were established for proanthocyanidins of Aesculus carnea, Vaccinium vitis idaea, Acacia, Hummulus as well as others and are considered typical for the majority of plant proanthocyanidins $(15,16)$. A re-investigation of the presence and amounts of the different proanthocyanidins in barley seems appropriate. Especially the presence of the B type proanthocyanidins together with the group containing an oxygen linkage according to SILBEREISEN and KRAFFCZYK and the absence of the A-2 type requires confirmation.

Measuring polyphenols in beer and brewing materials is difficult because of the large number of different compounds present including products of various degrees of polymerization, e.g. among proanthocyanidins (10). Several methods for quantitative estimation of proanthocyanidins, catechins and total polyphenols are in use. All quantitative estimations of proanthocyanidins are based on their conversion to red anthocyanidins upon heating in acidic solutions. This conversion is not quantitative as substantial amounts of brown phlobaphene-like polymers are formed along with the anthocyanidins. The yield of anthocyanidins has been reported to amount from c. $10 \%$ to as high as $27 \%$ depending on the solutions employed. In alcoholic solution the conversion yields about $18 \%$ (7). The majority of the methods for estimation of proanthocyanidins are based on the isolation of these compounds on a polyamide resin (Nylon-66, perlon or Polyclar AT), followed by heating of the adsorbate with alcoholic hydrochloric acid and spectrophotometric estimation of the resulting anthocyanidins $(14,19)$. The loss incured by the formation of large amounts of polymers is generally compensated for by using an appropriate standard such as leucocyanidin. These methods consider the proanthocyanidins, but not the catechins present in the sample.

Catechins and phenolic acids are adsorbed together with proanthocyanidins on the polya- 
mide resins but do not give anthocyanidins upon heating with dilute acids. Both catechins and proanthocyanidins react with vanillin in acidic media to form a red coloured complex and the determination of catechins is often based on this reaction. MCFARLANE et al. (21) used vanillin in conc. hydrochloric acid to estimate proanthocyanidins and catechins. The catechins were separated from the proanthocyanidins by chromatography on Polyclar AT. This metod determines only free catechins and not those undergoing polymerization. DADIC (7) described a method for simultaneous determination of anthocyanidins and catechins based on their specific absorption coefficients in the green and the blue. After heating the alcoholic hydrochloric acid solution containing proanthocyanidins and catechins, the absorbancies at two suitable wavelengths (545 and $455 \mathrm{~nm}$ ) are measured and from them the concentrations determined by application of binary analysis. The determinations made according to Dadic's method give, however, large standard deviations with replicate samples. This is in part due to the binary analysis used to calculate catechin and proanthocyanidin content as small variations in the absorbancies are reflected in large differences of both catechin and proanthocyanidin values.

JERUMANIS (18) used the colour reaction of ferric ammonium citrate with polyphenols to measure their amounts. The limitation of this method is that ferric salts also react with compounds such as phenolic acids in wort and beer. As the colour yield from different compounds depends on their chemical structure it is difficult to calibrate the method adequately.

If the same material is analysed with the different methods discussed, the results are not commensurable (Tables I, VI and also DADIC (7)). The individual method used on different materials provides adequate comparisons on the contents of proanthocyanidins and catechins. This is supported by the comparisons of grain extracts from ant-13 and Foma (Table I). It is doubtful if the calculated amounts of proanthocyanidins and catechins in a sample will stand up to a precise chemical analysis.

Mutation of the gene ant-13 has blocked the formation of anthocyanidins, flavan-3-ols and condensation products of flavan-3-ols. The pilot brews with this barley have revealed that the elimination of catechins and proanthocyanidins improves haze stability without adverse effects on taste and colour. A more refined assessment of the role of different polyphenols in haze formation will be possible, when mutants become available that only block the dimerization of flavan-3-ols and others that block the conversion of the hypothetical intermediate flavenol into flavan-3-ols. Such mutants are expected to form anthocyanidins and may accumulate the hypothetical intermediate in the grains in which the pathway leading to anthocyanidins is largely suppressed.

Mutant ant-13 has in field trials yielded 20$25 \%$ less than its mother variety Foma, possibly due to an extreme susceptibility towards powdery mildew. By crossing with high yielding varieties it is attempted to move the gene into more favorable genetic backgrounds and thereby to produce high yielding malting barley varieties containing this gene. Elimination of anthocyanidins, catechins and proanthocyanidins in all organs of the barley plant may limit seriously the disease resistance and yield which can be obtained. In such a case organ specific mutants which restrict the elimination of these flavonoids to the grain can be looked for. Finally, we screen for other mutant alleles of the ant13 gene with the aim of isolating an allele with less severe pleiotropic effects on yield.

\section{REFERENCES}

1. Ahrenst-LARSEN, B.: Nyt fors $ø$ gsbryggeri på Tuborg (in Danish with English summary). Brygmesteren 24, 109-128 (1967)

2. Analytica-EBC, Analysis Committee of European Brewery Convention, T.-M. Enari ed. Schweizer Brauerei-Rundschau, 3rd ed., Zürich, $87 \mathrm{pp}$. (1975)

3. Blom, J. \& A. BaK: Uber die Bestimmung von Amylasen durch Verflüssigung von Stärkekleister. Z. Physiol. Chem. 256, 197-207 (1938).

4. Blom, J.: Bestimmung von Kohlensâure im Bier. Brauwelt 95, 645-646 (1955) 
5. Bцoм, J.: Über die Bestimmung der Haltbarkeit des Schaumes. Eu. Brew. Con. Proc. Cong., Copenhagen 1957, 51.56(1957)

6. Chapon, L. \& M. Chemardin: Etude sur le trouble au froid. Eu. Brew. Con. Proc. Cong., Madrid 1967, 389-405 (1968)

7. Dadic, M.: Analytical methods for polyphenols in brewing. II: A new method for determination of anthocyanogens and chatechins (tanninogens) in wort and beer. Am. Soc. Brew. Chem. Proc. 1971, 159-170(1971)

8. DADIC, M. \& N. M. MORrison: Analytical methods for polyphenols in brewing III. Simultaneous determination of anthocyanogens and catechins (tanninogens) in brewing materials. Am. Soc. Brew. Chem. Proc. 1972, 50-56 (1972)

9. Gramshaw, J. W.: Beer polyphenols and the chemical basis of haze formation I. Phenolic constituents of beer and its raw materials. Tech. Q. Master B rew. Ass. Am. 6, 239-251 (1969)

10. Gramshaw, J. W.: Beer polyphenols and the chemical basis of haze formation III. The polymerization of polyphenols and their reaction in beer. Tech. Q. Master Brew. Ass. Am. 7, 167181 (1970)

11. Grisebach, H.: Recent investigation on the biosynthesis of flavonoids. In Recent Advances in Phytochemistry. T. J. MABRY, R. E. Alston \& V. C. RuneCKLES eds. Vol. 1. Appleton-CenturyCrofts, New York, pp. 379-406 (1968)

12. Gustafsson, Ȧ., A. Hagberg, U. Lundquist \& G. Persson: A proposed system of symbols for the collection of barley mutants at Svalöv. Hereditas 62, 409-414 (1969)

13. Harborne, J. B.: Flavonoids. In Phytochemistry Vol. 2. L. P. MiLler ed. Van Nostrand-Reynold Co., pp. 364-371 (1973)

14. HaRris, G. \& R. W. RicketTs: Beer haze - the problem and a solution. Eu. Brew. Con. Proc. Cong., Rome 1959, 290-302 (1959)

15. HASLAM, E.: Natural proanthocyanidins. In The Flavonoids. J. B. Harborne, T. J. Mabry \& H. MABRY eds. Chapman and Hall, London, pp. 505559 (1975)

16. HASLAM, E.: The chemistry and biochemistry of plant proanthocyanidins. In Topics in Flavonoid Chemistry and Biochemistry. L. FARKAS ed. Proc. 4th Hungarian Bioflavonoid Symp. Elsevier, Amsterdam, pp. 77-99 (1975)

17. Hough, J. S., D. E. Briggs \& R. Stevens: Malting and brewing science. Chapman and Hall, London, p. 362 (1971)

18. Jerumanis, J.: Simplification et amélioration de la méthode de dosage des polyphénols totaux en brasserie. Bull. Ass. Anc. Etud. Ec. Super. Brass. Univ. Louvain 64, 223-240 (1968)

19. McFarlane, W. D.: Determination of anthocyanogens. J. Inst. B rew. 67, 502-506 (1961)

20. McFarlane, W. D. \& P. T. Sword: Determination of anthocyanogens. III. Analysis of barley and malt. J. Inst. Brew. 68, 344-350 (1962)

21. McFarlane, W. D., P. T. Sword \& G. BlinofF: Catechins - tannins in brewing. Eu. Brew. Con. Proc. Cong., Brussels 1963, 174-181 (1964)

22. Pollock, J. R. A., A. A. Pool \& T. Reynolds: Anthocyanogens in barley and other cereals and their fate during malting. J. Inst. Brew. 66, 389394 (1960)

23. Satake, K., T. Okuyamat, M. Ohashi \& T. SHINODA: The spectrophotometric determination of amines, amino acids and peptides with 2,4,6trinitrobenzene-1-sulfonic acid. J. Biochem. (Tokyo) 47, 654-660(1960)

24. Silbereisen, K. \& F. KRAFFCZyK: Isolierung und Struktur biflavanoider Proanthocyanidine (Anthocyanogene) der Gerste. Monatschr. Brau. 20, 217-223 (1967)

25. SøRENSEn, J. A.: Penetration of gases into bottled beer sealed with crowns with discs of cork and plastic. Eu. Brew. Con. Proc. Cong., Rome 1959, 220-226 (1959)

26. TROLle, B.: Bryggerimæssige betragtninger vedrørende maltbyg. (In Danish). Brygmesteren $17,45-55(1960)$

27. Wejnges, K., W. Bähr, W. Ebert, K. Goritz \& H.-D. MARX: Die dimeren Proanthocyanidine. In Fortschritte der Chemie organischer Naturstoffe, Vol. 27. Springer Verlag, Wien, pp. 234-245 (1969)

28. Danish Patent Application no. 4640/75. 